\title{
FEEDING OF TWO CICHLIDAE SPECIES (PERCIFORMES) IN AN HYPERTROPHIC URBAN LAKE
}

\author{
Alejandro Yafe ${ }^{1}$ \\ Marcelo Loureiro ${ }^{1}$ \\ Flavio Scasso ${ }^{2}$ \\ Federico Quintans ${ }^{2}$
}

\begin{abstract}
Diet of two cichlid species, Cichlasoma facetum (Jenyns, 1842), and Gymnogeophagus rhabdotus Hensel, 1870, was studied in Rodó Lake, an urban hypertrophic lake in Uruguay. The stomach contents from 192 individuals of C. facetum and 202 of G. rhabdotus, obtained through seasonal sampling in the year 2000, were analyzed. The occurrence frequency and the alimentary importance index of each food item were calculated for each season and size class in both species. Cichlasoma facetum fed upon insects (mainly chironomid larvae and pupae), fish (Cnesterodon decemmaculatus Jenyns, 1842), and vegetals (algae, periphyton and macrophytes debris); large individuals also fed upon the freshwater shrimp Palaemonetes argentinus Nobili, 1901. Gymnogeophagus rhabdotus consumed zooplankton (mainly copepods), vegetals (algae and detritus) and Chironomidae larvae in a lesser extent.
\end{abstract}

KEYWORDS. Diet, freshwater trophic web, Cichlasoma, Gymnogeophagus.

\section{INTRODUCTION}

Restoration of aquatic systems includes two biomanipulation approaches: bottomup procedures, where the trophic web is manipulated in the lower trophic levels (i.e. reduction in the nutrients input) and top-down procedures, where the higher trophic levels are manipulated (i.e. stocking of piscivorous fish, removal of plancktivorous fish) (PERROw et al., 1997). One of the first steps in the processes of top-down biomanipulation is the knowledge of the trophic function of the key species that compose the system (Perrow et al., 1997). Cichlasoma facetum (Jenyns, 1842) and Gymnogeophagus rhabdotus Hensel, 1870 are among the most abundant species in Lake Rodó (Montevideo, Uruguay), an urban system dominated by a small omnivorous fish, Cnesterodon decemmaculatus Jenyns, 1842 (Scasso et al., 2001).

1. Sección Vertebrados, Facultad de Ciencias, Iguá 4225, Montevideo 11400, Uruguay.

2. Sección Limnología, Facultad de Ciencias, Iguá 4225, Montevideo 11400, Uruguay. 
Only diet of $C$. facetum has been studied in several natural systems different from Lake Rodó. RINGUELET (1975) mentioned that this species feeds on micro and meso sized animals, while Escalante (1984), GutiérReZ et al. (1986) and Ruzz et al. (1992) described it as omnivorous.

The diet of these two species was studied in order to know their role in the trophic web of Lake Rodó.

\section{MATERIAL AND METHODS}

Lake Rodó $\left(34^{\circ} 55^{\prime} \mathrm{S}, 56^{\circ} 10^{\prime} \mathrm{W}\right)$ is a small (1.3 ha), shallow (max. depth $2.4 \mathrm{~m}$ ) and hypertrophic man-made lake, with the absence of real littoral zone due to the presence of vertical stone walls. It is located in Montevideo city and has been physically and biologically characterized by Scasso et al. (2001), who considered the system as hypertrophic, with a conductivity between 427 and $1103 \mu \mathrm{S} \mathrm{cm}^{-1}$ The eutrophication process was conditioned by a high nutrient input from the surrounding urban area, and the principal consequences of this process were the loss of aesthetic and recreational values. Its high turbidity is attributed to algae biomass.

Sampling of fish was carried out in summer (February), autumn (May), winter (August), and spring (November) of 2000, in the morning and evening. Fish were captured by electrofishing (Sachs Elektrofischfanggerate GmbH D-88299 Leutkirch), covering the whole lake. A selection of individuals was done in order to obtain a similar number of each size class. Captured fish were sacrificed and preserved in ice until their stomachs were removed in the laboratory.

Fish were measured (standard length and total length) and weighted; the dissected stomachs were fixed in formaline $10 \%$ and the contents were analyzed with a dissecting microscope. The repletion index was calculated according to BERHANT (1973). The contribution of each alimentary item to the whole volume of the stomach content was measured by the semi-quantitative scale of GuILLEN \& GranADO (1984). The qualitative analysis of the stomach contents was done using the occurrence method according to HysLop (1980).

For analysis purposes some items were grouped as follows: Cladocera and Copepoda as zooplankton; Hemiptera, Coleoptera, and Chironomidae (Diptera) larvae and pupae as aquatic insects; algae periphyton and detritus as vegetal material.

The alimentary importance index (AII) was calculated. This index relates the frequency that each item appears in the diet with the proportion of the same item in the stomach content (GRANADO \& GARCIA-Novo, 1986). The intestinal coefficient (IQ) was calculated through the expression IQ = IL/TL, where IL is the intestine length and TL is the total length.

To check for differences in diet due to different sizes of captured fish, three artificial size classes were determined for each species; for C. facetum, class I $(<40 \mathrm{~mm} \mathrm{SL})$, class II $(40-60 \mathrm{~mm})$ and class III $(>60 \mathrm{~mm})$; for $G$. rhabdotus, class I $(<35 \mathrm{~mm} \mathrm{SL})$, class II $(35-50 \mathrm{~mm})$ and class III $(>50 \mathrm{~mm})$. Size limits were chosen in order to roughly separate juveniles from young and older adults.

The results were compared by the non parametric Kruskal-Wallis ANOVA, Mann-Whitney U test, and a non-parametric multiple comparison (Q test) (Dunn, 1964 apud ZAR, 1999); with $\alpha=0.05$ in every case. To quantify the similarity in the diet between species and among size classes of the same species, the feeding overlap (C) was calculated according to HoRN (1966).

\section{RESULTS}

No statistical differences in stomach contents of the two species were found between morning and evening samples, so data from each season were pooled. We analyzed the stomach contents of 192 individuals of $C$. facetum, mean standard length $54 \mathrm{~mm}$ (range: 13-158), mean weight $15.6 \mathrm{~g}$ (range: $0.07-219$ ). Thirty five percent of the stomachs were empty. The lowest mean value of repletion (1.1) was observed in winter and this was 
significantly different from summer (1.9) $(\mathrm{Q}=3.144, \mathrm{p}=0.01)$ and $\operatorname{spring}(1.9)(\mathrm{Q}=3.144$, $\mathrm{p}=0.01$ ) (fig. 1). Among the 22 food items found in the stomach content of this species (tab. I), those with higher mean frequency and AII were: aquatic insects $(0.29,0.25)$, vegetal material $(0.28,0.18)$, and fish $(0.20,0.20)$. These items were also the most important in each season (fig. 2). When considered each size class separately, the same items remained as the most important (fig. 3). The highest value of alimentary overlap ( 0.78$)$ was found between class II and III, while the lowest value $(0.42)$ was observed between class I and III. The overlap between class I and II was 0.74 .

The stomach contents of 202 individuals of G. rhabdotus were analyzed, mean standard length $43.7 \mathrm{~mm}$ (range: 18-75) and mean weight $4.06 \mathrm{~g}$ (range: $0.19-14.7$ ). From the total stomachs, $49.0 \%$ were empty. The highest mean value was observed in summer (1.4), and this value was significantly different from autumn $(0.6)(\mathrm{Q}=3.765, \mathrm{p}=0.001)$ and winter $(0.8)(\mathrm{Q}=2.936, \mathrm{p}=0.02)$ (fig. 1). Among the 17 food items found in the stomach content of this species (tab. I), the most frequent were: vegetal material ( 0.38$)$, zooplankton (0.34), Chironomidae larvae (0.17), and sediment (0.17). Copepoda ( 0.24$)$ and Cladocera $(0.12)$ were the zooplankton groups more frequently observed. The items with higher AII

Table I. Food items found in the stomach contents of two cichlid species in Lake Rodó, Montevideo, Uruguay, during 2000. (1, Cichlasoma facetum; 2, Gymnogeophagus rhabdotus).

\begin{tabular}{|c|c|c|c|c|}
\hline & & & 1 & 2 \\
\hline \multirow[t]{6}{*}{ Crustacea } & Ostracoda & & & $\mathrm{X}$ \\
\hline & Cladocera & Individuals & $\mathrm{X}$ & $\mathrm{X}$ \\
\hline & & Ephippial eggs & & $\mathrm{X}$ \\
\hline & Copepoda & & $\mathrm{X}$ & $\mathrm{X}$ \\
\hline & Amphipoda & & $\mathrm{X}$ & $\mathrm{X}$ \\
\hline & Decapoda & P. argentinus & $\mathrm{X}$ & $\mathrm{X}$ \\
\hline \multirow[t]{8}{*}{ Insecta } & Hemiptera & & $\mathrm{X}$ & \\
\hline & Coleoptera & & $\mathrm{X}$ & \\
\hline & Hymenoptera & Ants & & $\mathrm{X}$ \\
\hline & & Bees & $\mathrm{X}$ & \\
\hline & Diptera & Chironomid larvae & $\mathrm{X}$ & $\mathrm{X}$ \\
\hline & & Chironomid pupae & $\mathrm{X}$ & $\mathrm{X}$ \\
\hline & & Adults & $\mathrm{X}$ & \\
\hline & Undetermined & & $\mathrm{X}$ & \\
\hline \multirow[t]{2}{*}{ Arachnida } & Araneae & & $\mathrm{X}$ & \\
\hline & Acari & & & $\mathrm{X}$ \\
\hline Mollusca & Gastropoda & Heleobia sp. & $\mathrm{X}$ & \\
\hline \multirow[t]{2}{*}{ Annelida } & Oligochaeta & Enchytraeidae & & $\mathrm{X}$ \\
\hline & & Earth worms & $\mathrm{X}$ & \\
\hline Bryozoa & & Estatoblasts & $\mathrm{X}$ & $\mathrm{X}$ \\
\hline \multirow{2}{*}{ Actinopterygii } & & Cnesterodon decemmaculatus & $\mathrm{X}$ & \\
\hline & & Undetermined fishes & $\mathrm{X}$ & \\
\hline Undetermined eggs & & & $\mathrm{X}$ & $\mathrm{X}$ \\
\hline Vegetal material & & & $\mathrm{X}$ & $\mathrm{X}$ \\
\hline Seeds & & & $\mathrm{X}$ & $\mathrm{X}$ \\
\hline Sediment & & & $\mathrm{X}$ & $\mathrm{X}$ \\
\hline Undetermined material & & & $\mathrm{X}$ & $\mathrm{X}$ \\
\hline
\end{tabular}




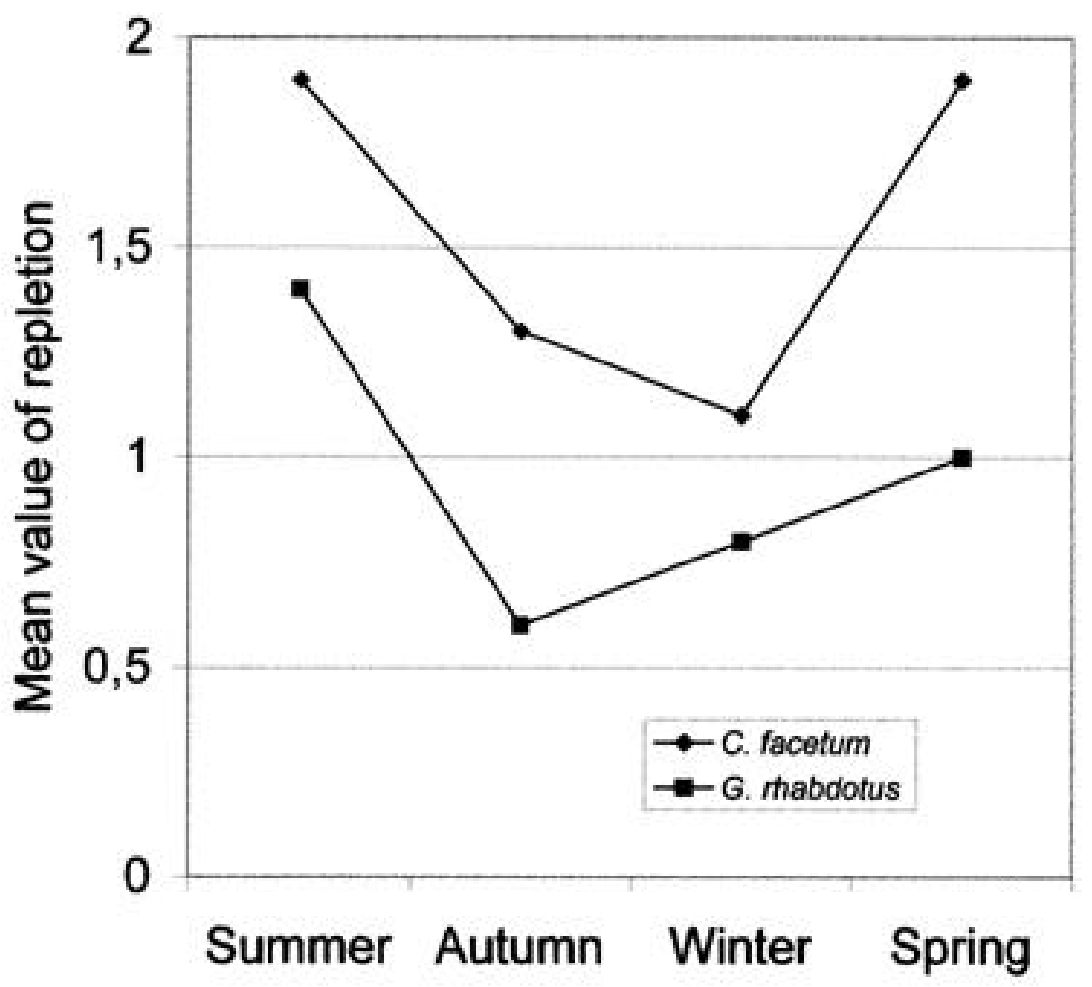

Fig. 1. Annual variation in the mean repletion of Cichlasoma facetum and Gymnogeophagus rhabdotus in lake Rodó, Montevideo, Uruguay during 2000.

were zooplankton ( 0.25$)$ and vegetal material (0.24); within the former, Copepoda presented the highest AII (0.17). High annual variation was observed in all items consumed (fig. 4). When considered each size class separately, the same items remained as the most important (fig. 5). The highest value of alimentary overlap (0.76) observed between classes I and II, and the lowest $(0.62)$ between classes I and III. The overlap between classes II and III was 0.71 . The average feeding overlap between $C$. facetum and G. rhabdotus along the year was 0.28 . Considering each season separately, the highest value was found in summer $(0.65)$. In autumn the feeding overlap was 0.22 , in winter 0.37 and the least value was obtained in spring $(0.15)$.

The IQ value obtained for $C$. facetum ( 0.65$)$ was significantly different ( $U=3810$, $\mathrm{p}=0.00)$ from $G$. rhabdotus $(0.91)$. 

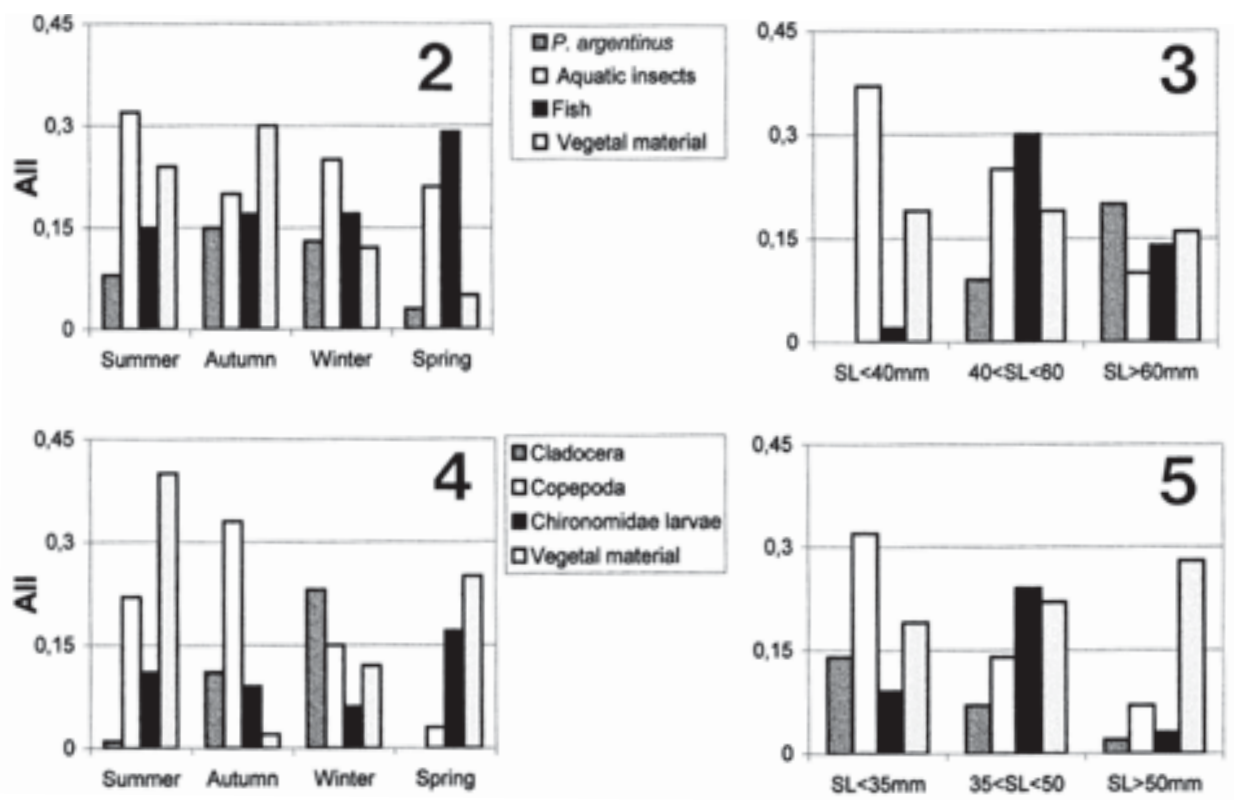

Figs. 2-5. Alimentary importance index (AII) of the most important food items in lake Rodó, Montevideo, Uruguay during 2000. Annual variations: 2, Cichlasoma facetum; 4, Gymnogeophagus rhabdotus. For each size class: 3, C. facetum; 5, G. rhabdotus (SL, standard length).

\section{DISCUSSION}

Cichlasoma facetum and G. rhabdotus presented an omnivorous diet. Besides, the AII values of the food items consumed never reached the 0.3 limit value proposed by GranADO \& GARCIA-Novo (1986) to be considered as a main item. In spite of these facts, there are some differences between the species analyzed. Cichlasoma facetum presented some tendency to carnivory. Insects and fish were the food items most consumed, the former by size classes I and II while the later by size classes II and III. In size class III, the freshwater shrimp Palaemonetes argentinus Nobili, 1901 was also in the diet. These alimentary preferences were also observed in previous studies in other environments (Ringuelet, 1975; EsCAlante, 1984; GutierRez et al., 1986; Ruiz et al., 1992). As observed by GutierRez et al. (1986), vegetal material was also well represented in the stomach contents in all size classes of this species.

The differential exploitation of the resource fish is determining the low alimentary overlap among individuals of size class I and the others. This item was absent from the stomach contents of the smallest individuals in all seasons, except in spring, where the presence of $C$. decemmaculatus young of the year allowed $C$. facetum juveniles to feed upon this prey. 
The most consumed items of $G$. rhabdotus was zooplankton (mainly copepods) closely followed by vegetal material. There are no known previous studies on the diet of this species. Escalante (1984) mentioned a similar diet in G. australis Eigenmann, 1907, a phylogenetically related species with similar morphology (REIS \& MALABARBA, 1988). The lowest feeding overlap value between size classes evidences an ontogenetic diet change. The ingestion of zooplankton decreased in larger sizes, whereas the ingestion of vegetal material increased. KRAMER \& BRYANT (1995) have already observed this tendency in seven species of neotropical omnivorous fish.

The IQ values obtained reflect quite well the differences in diet observed in the species studied; the lower value in the more carnivorous $C$. facetum and the higher in $G$. rhabdotus. In both species the mean repletion in summer was significantly higher than in winter, indicating a higher feeding activity in that time of the year. In summer, fish need more food for the basal metabolism and also to cover the increase in the growth rate related to higher temperatures (MANN \& ORR, 1969; WotTON et al., 1980). In general, the differences in the food consumed resulted in a low diet overlap between species. Bigger preys such as fish, various insect species (Hemiptera, Coleoptera, bees), and earth worms were absent from $G$. rhabdotus stomachs. The higher overlap in the diet between them observed in summer is probably due to the increase in food diversity (HARTz et al., 1996).

In Lake Rodó, the abundant population of small omnivorous fish ( C. decemmaculatus) maintains a high predation pressure on zooplankton, restricting the abundance of largebodied herbivorous, which in turn, allow an increase in microalgae biomass and a decrease in water transparency (ScASso et al., 2001). In this context, $C$. facetum could have a clear beneficial effect on the water quality by predating over $C$. decemmaculatus. The main food source of $G$. rhabdotus is zooplankton, and this could be acting against water transparency. In natural ecosystems, G. rhabdotus can reach total lengths of about 150 $\mathrm{mm}$. The smaller sizes found in Lake Rodó could result in a higher predation pressure on zooplankton as observed in this paper for this species. As an omnivorous species, its effects over the food web are not as direct as a strict planktivorous one (GERKING, 1994).

Acknowledgments. To Dr. Nestor Mazzeo (Facultad de Ciencias, Montevideo, Uruguay) for his correction of the manuscript; MSc. Enrique Morelli, Msc. Ana Verdi, and Lic. Rodrigo Ponce de León (Facultad de Ciencias, Montevideo, Uruguay) for their help in the identification of prey items. This study was benefited in part by the financial support of the Municipality of Montevideo.

\section{REFERENCES}

BerHant, J. A. 1973. Bioles des stades juveniles des teleostens Mugilidae Mugil auratus, Risso 1810, Mugil capito, Cuvier 1829 et Mugil saliens Risso, 1810. Aquaculture, New York, 2:251-266.

Escalante, A. 1984. Contribución al conocimiento de las relaciones tróficas de peces de agua dulce del área platense. IV. Dos especies de Cichlidae y miscelánea. Limnobios, La Plata, 2(8):562-578.

Gerking, S. D. 1994. Feeding ecology of fish. San Diego, Academic. 416p.

Granado, C. \& García-Novo, F. 1986. Feeding habitats of the fish community in a eutrophic reservoir in Spain. Ekol. Polska, Varsovia, 34(1):95-110.

Guillen, E. \& Granado, C. 1984. Alimentación de la ictiofauna del embalse Torrejón (Río Tajo, Cáceres). Limnética, Madrid, 1:304-310.

Gutierrez, M.; Bistoni, M. A. \& Haro, J. G. 1986. Hábitos alimentarios de Cichlasoma facetum (Jenyns)(Pisces, Cichlidae) en el Río Primero (Córdoba, Argentina). Revta Asoc. Cienc. Nat. Lit., Santo Tomé, 17(1):115-126.

Iheringia, Sér. Zool., Porto Alegre, 92(4):73-79, 30 de dezembro 2002 
Hartz, S. M.; Machado, C. \& Barbieri, G. 1996. Alimentação das especies de Astyanax Baird \& Girard, 1854 ocorrentes na lagoa Caconde, RS, Brasil (Teleostei, Characidae). UNIMAR, Maringá, 18(2): 269-281.

Horn, H. S. 1966. Measure of "overlap" in comparative ecological studies. Am. Nat., Chicago, 100:419-424.

Hyslop, E. J. 1980. Stomach content analysis. A review of methods and their application. J. Fish Biol., London, 17:411-429.

Kramer, D. L. \& Bryant, M. J. 1995. Intestine length in the fish of a tropical stream: 2. Relationships to diet, the long and short of a convoluted issue. Env. Biol. Fish, Dordrecht, 42:129-141.

MANN, R. H. \& ORR, D. R. 1969. A preliminary study of the feeding relationships of fish in a hard-water and a soft-water stream in southern England. J. Fish Biol., London, 1:31-44.

Perrow, M. R.; Meijer, M. L. et al. 1997. Biomanipulation in shallow lakes: state of the art. Hydrobiologia, Dordrecht, 342/343:355-365.

Reis, R. E. \& Malabarba, L. R. 1988. Revision of the neotropical cichlid genus Gymnogeophagus Ribeiro, 1918, with descriptions of two new species (Pisces, Perciformes). Revta bras. Zool., São Paulo, 4(4):259-305.

Ringuelet, R. A. 1975. Zoogeografía y ecología de los peces de aguas continentales de la Argentina y consideraciones sobre las áreas ictiológicas de América del Sur. Ecosur, Corrientes, 2(3):1-122.

Ruiz, V. H.; Moyano, H. I. \& Marchant, M. 1992. Aspectos biológicos del pez exótico C. facetum (Jenyns 1842)(Pisces, Ciclidae) en aguas dulces de Concepción. Boln Soc. Biol. Concepción, Concepción, 63:193-201.

Scasso, F.; Mazzeo, N. et al. 2001. Limnological changes in a sub-tropical shallow hypertrophic lake during its restoration: two years of a whole-lake experiment. Aquatic Conserv. Mar. Freshw. Ecosyst., New York, 11:31-44.

Wotton, R.; Allen, J. \& Cole, S. 1980. Effect of body weight and temperature on the maximum daily food consumption of Gasterosteus aculeatus L. and Phoxinus phoxinus (L.): selecting an appropriate model. J. Fish Biol., London, 17:695-705.

ZAR, J. H. 1999. Biostatistical analysis. New Jersey, Prentice Hall. 663p.

Recebido em 25.03.2002; aceito em 30.09.2002

Iheringia, Sér. Zool., Porto Alegre, 92(4):73-79, 30 de dezembro 2002 